\title{
The effect of traction with two different load on clinic and functional status of patients with subacute lumbar disc herniation
}

\author{
Farklı ağırlıklarda uygulanan traksiyonun subakut lomber disk hernili \\ hastaların klinik ve fonksiyonel durumu üzerine etkisi
}

\author{
Sadiye MURAT $^{1}$, Kaan UZUNCA ${ }^{2}$, Nuran ERDEN ${ }^{3}$
}

ABSTRACT

The aim of the study was to investigate the effects of 2 different traction loads on physical and clinical status in patients with subacute lomber disc hernia. Seventy patients were included in the study, and 9 of them withdrew their consent. Sixty-one patients were randomised. Patients in Group $1(n=30)$ and $2(n=31)$ received intermittent traction load of $35-50 \%$ and $10-20 \%$ of their body weights. Exercise program was demonstrated to both groups, and the patients were trained about prevention measures for low back pain. Treatment results of all patients were evaluated with visual analog scale, short-form 36, Oswestry Low Back Pain Disability Index, Roland Morris Disability Questionnaire before and in intragroup comparisons statistically significant difference was found before and after treatment, and also before and 40 days after treatment. While outcome evaluation scales revealed improvements in both groups ( $p>0.05)$. These results suggest that nearly half of the lumbar hernia patients can improve within about 2-6 weeks irrespective of the treatment, lomber hernia can benefit from physical therapy modalities and exercise other than lomber traction.

Keywords: Lumbar disc herniation, traction, functional status öz

Çalışmada, subakut lomber disk hernisi olan hastalarda, iki farklı ağırlık ile yapılan traksiyonun klinik, fonksiyonel durum ve yaşam kalitesi üzerine olan etkilerini araştırmak amaçlandı. Çalışmaya 70 hasta alındı. Dokuz hasta çalışmaya katılmak istemedi. 61 hasta randomize edildi. Grup 1'e ( $n=30)$ : vücut ağırlığının \%3550'si Grup 2'ye (n=31) vücut ağırlığının \%10-20 'si kuvvetinde "intermittant traksiyon" uygulandı. Her iki gruba egzersiz programı gösterildi. Bel ağrısından korunma konusunda eğitildi. Tedavi; tedavi öncesi, tedavi sonrası (10. gün) ve tedaviden bir ay sonra (40. gün) yapılan visüel analog skala, short-form 36, Oswestry Bel Ağrısı Özürlülük ve Roland-Morris Fonksiyonel Değerlendirme formları ile değerlendirildi. Çalışmada, sonuç değerlendirme ölçekleri ile iki grupta iyileşme görüldü $(p>0,05)$. Grupların kendi içlerinde yapılan karşılaştırma sonuçlarında ise VAS ölçümleri, Oswestry Bel Ağrısı Özürlülük, Roland-Morris Fonksiyonel Değerlendirme sonuçları ve SF-36 sorgulamasında tedavi öncesi-tedavi sonrası ve tedavi öncesi- 40 gün sonraki değerlendirme arasında anlamlı istatistiksel fark bulundu $(p<0,05)$. Bu sonuçlarla lomber disk hernisinin yaklaşık \%50'sinde tedaviden bağımsız, 2-6 haftada doğal seyri sonucu iyileştiği, traksiyon dışında fizik tedavi modaliteleri ve egzersizin iyileşmeye katkı sağladığı düşünüldü.

Anahtar kelimeler: Lomber disk hernisi, traksiyon, fonksiyonel durum

\section{INTRODUCTION}

Low back pain is one of the most common health problems in the world ${ }^{1}$. Although its incidence changes from country to country, low back pain is always among the top 10 diseases $^{2}$. Incidence studies show that $70-80 \%$ of the active working population has a back pain problem for a period ${ }^{3}$. Repeated treatments lead to expensive medical and social problem as they require serious job loss and social support ${ }^{4}$. Waist pain can be seen as acute, subacute (persisting for 6-8 weeks- 3 months) and chronic (persisting at

Received: 20.12 .2017

Accepted: 03.03.2018

${ }^{1}$ Istanbul Medeniyet University, Goztepe Education and Research Hospital, Department of Physical Medicine and Rehabilitation, Istanbul, Turkey

${ }^{2}$ Medikent Private Hospital, Department of Physical Medicine and Rehabilitation, Luleburgaz, Kırklareli, Turkey

${ }^{3}$ Nisantasi University, Vocational School, Departman of Physiotherapy, Istanbul, Turkey

Yazışma adresi: Sadiye Murat, Istanbul Medeniyet University, Goztepe Education and Research Hospital, Department of Physical Medicine and Rehabilitation, Istanbul, Turkey

e-mail: samurftr@gmail.com 
least 3 months) pain 5 . The etiology of $85 \%$ of back pain is idiopathic. The lumbar disc hernia is one of the remaining $15 \%$ of the causes of specific back pa$\mathrm{in}^{6}$.

Most of the patients with lumbar disc hernia respond adequately to conservative treatment, only $5-10 \%$ of them require surgical treatment. Conservative treatment includes resting, pharmacological treatment, physical medicine and rehabilitation applications (analgesic currents, hot-cold applications, traction, exercise), manipulation, spinal orthoses, epidural and paravertebral stem blocks ${ }^{1,7,8}$. One of the conservative treatment approaches is the traction performed with the physical therapy applications. Traction enlarges the intervertebral disc space and the foramina passed by the spinal nerves so it regulates circulation, reduces edema and regional muscle spasm. The longitudinal tensile loading with intervertebral discoid elongation provides the relaxation of surrounding tissue and reduces intradiscal pressure? . $^{9}$

Studies have shown that the pain level of patients with low back pain improves with traction applied at different forces and durations ${ }^{10-14}$. There are conflicting results in randomized controlled trials conducted in recent years to assess the effectiveness of traction in reducing pain in patients with lumbar disc hernia ${ }^{10-14}$. These studies have been considered with suspicion because of the large number of treatment parameters and methodological faults ${ }^{15}$.

In this study which aimed two different applications of traction as a physical therapy method in patients with subacute lumbar disc hernia on the effect of pain, clinical and functional status.

\section{MATERIALS and METHODS}

Seventy patients aged $20-50$ years, diagnosed with subacute lumbar disc herniation by clinical evaluation and lumbar MRI complained about pain in the back of their legs for at least 2 weeks and less than 3 months. A prospective randomized controlled and double-blind study was planned. Patients who were pregnant, and those had lumbar spine surgery, progressive neurological loss, umbilical, hiatal and inguinal hernia, malignancy, infectious disease, inflammatory pathologies, severe lung and cardiovascular disease and patients who had previously undergone traction therapy were not included in the study.

In order to exclude other etiologic factors which might lead to low back, and leg pain, radiologic examinations, laboratory tests and MRI were performed in all patients before treatment.

In the study, 70 patients were evaluated before randomization. Out of 70 patients 9 were excluded due to their will. A total of 61 patients were divided into two groups by simple randomization using $n, n+1$ principle. Group I ( $\mathrm{n}: 30)$ consisted of patients enumerated with odd and Group II (n:31) with even numbers.

University ethics committee approval and written and verbal informed consent forms were taken from the patients.

Four patients in Group I were excluded at the second control, because three had severe pain at the end of treatment and one had neurological deficiency during follow-up. Two patients in Group 2 were excluded from the study upon their will, and two patients were not included in the study because were lost to follow-up.

During the study, all clinical and laboratory evaluations were performed by the same physician (SM) who was unaware of the double group randomization. Patients were not aware of the applied traction method. The results were evaluated by a statistical expert who was blinded to the study.

A total of 10 sessions of physical therapy program were given once a day and five times a week for both groups. The physical therapy program of lumbar traction, infrared and exercise program were given to both of the groups. The intermittent traction force was applied for 20 minutes to both groups. Groups 1 , 
and 2 were exposed to loads weighing $35-50 \%$, and $10-20 \%$ of the body weight, respectively. For both groups physical therapy program was demonstrated by the same therapist who planned the exercise program in order to strengthen the abdominal and back muscles. Patient education was provided about measures for the prevention of low back pain. To determine the analgesic requirement, they were allowed to use up to $4000 \mathrm{mg}$ of paracetamol tablets when they have pain and were asked to note the number of tablets they needed.

As the treadmill, traction unit (Enraf-Nosius Eltrac 471 , Netherlands, 2000) was used. Group 1 was exposed to gradually increasing intermittent traction (40 sec pull, 20 sec relaxation) force ranging between $35 \%$, and $50 \%$ of the body weight according to their tolerances. Group 1 was exposed to gradually increasing placebo intermittent traction (40 sec pull, $20 \mathrm{sec}$ relaxation) force ranging between $10 \%$, and $20 \%$ of the body weight according to their tolerances. A 250 watt infrared was applied for 20 mins $50 \mathrm{~cm}$ from the dotted area.

Clinical and functional status were evaluated before treatment, at the end of the treatment and 1 month after the treatment. The severity of pain was assessed with a 100-mm Visual Analogue Scale (VAS) (no pain: $0 \mathrm{~mm}$, the most severe pain: $100 \mathrm{~mm}$ ). Patients' severity of back pain was interrogated separately during rest and movement ${ }^{19}$.

For functional evaluation Roland Morris Disability Questionnaire (RDQ), each "yes" response scored 1, "no" response 0 point and a total score of 24 questions were calculated ${ }^{20}$. The Oswestry Disability Index (ODI) form had 10 questions, and each scored between 0 and 5 points. The total score obtained was multiplied by 2 and the result was given as a percentage ${ }^{21}$.

The quality of life was assessed with Short-Form 36 (SF-36) which consists of 9 sub-criteria including 36 questions including physical and social functioning, role limitations caused by physical or emotional prob- lems, mental health, energy / vitality, pain, general perception of health and health condition compared to the last year. Each subtitle is scored between 0 and 100 in itself. The best score was $100^{22}$.

\section{STATISTICAL ANALYSIS}

The normal distribution of the data was assessed by the single sample Kolmogorov Smirnov test. The comparison of treatment and control groups' data was assessed by t test in independent groups for normal distribution variables, and by Mann Whitney $U$ test for variables without normal distribution. A chisquare test was used to investigate the difference between groups of categorical variables. ANOVA test was used for repeated measures in comparison of repeated measures in groups with normal distribution. Friedman's ANOVA tests were used to compare measures with non-normal distribution, and the Bonferroni multiple comparison test for determination of significant differences (if any). Statistical evaluations were performed in Statistica vs 7.0 (License Code: 31N6YUCV38). $p<0.05$ was considered statistically significant.

\section{RESULTS}

Sixty-one patients with lumbar disc hernia were included in the study. Group 1 consisted of 30 patients who underwent traction and Group 2 (control group) consisted of 31 patients who underwent placebo traction. There was no significant difference between the two groups in terms of age, body mass index (BMI), average disease duration, gender, education level and occupations (Table 1).

All patients completed the physical therapy program. Twenty-six patients in Group 1, and 27 in Group 2 came for control a month after completion of the treatment. One person was unable to complete the treatment due to lumbar disc operation, three patients did not come to the control, and four persons were excluded due to violation of the treatment protocol. 
Table 1. Demographic characteristics of two groups.

\begin{tabular}{|c|c|c|c|c|}
\hline & & Group $1(n=30)$ & Group 2 (n=31) & $\mathbf{p}$ \\
\hline \multicolumn{2}{|l|}{ Age (years) Mean $\pm S D$} & $37,13 \pm 8,81$ & $39,19 \pm 10,18$ & 0,402 \\
\hline \multicolumn{2}{|l|}{ BMI $\left(\mathrm{kg} / \mathrm{m}^{2}\right)$ Mean $\pm S D$} & $25,94 \pm 4,65$ & $26,46 \pm 4,37$ & 0,651 \\
\hline \multicolumn{2}{|c|}{ Duration of illness (day) Mean \pm SD } & $41,53 \pm 22,33$ & $50,48 \pm 26,51$ & 0,160 \\
\hline \multirow[t]{3}{*}{ Gender n (\%) } & Female & $14(6,7)$ & $18(58,1)$ & \\
\hline & Male & $16(53,3)$ & $13(41,9)$ & 0,373 \\
\hline & Primary school & $11(36,7)$ & $14(45,2)$ & \\
\hline \multirow[t]{3}{*}{ Level of education $\mathrm{n}(\%)$} & Middle school & $6(20)$ & $8(25,8)$ & 0,323 \\
\hline & High school & $6(20)$ & $7(22,6)$ & \\
\hline & University & $7(23,3)$ & $2(6,4)$ & \\
\hline \multirow[t]{4}{*}{ Job n (\%) } & Housewife & $7(23,3)$ & $13(41,9)$ & \\
\hline & Worker & $10(33,3)$ & $12(38,7)$ & 0,155 \\
\hline & Officer & $11(36,7)$ & $4(12,9)$ & \\
\hline & Retired & $2(6,7)$ & $2(6,5)$ & \\
\hline
\end{tabular}

SD: Standard Deviation, ${ }^{*} p<0.05$ significant difference was found, BMI: Body mass index

Table 2. Two groups of pain scores, Oswestry Disability Index and Roland Morris DisabilityQuestionnaire results were administered baseline, first and second control.

\begin{tabular}{|c|c|c|c|c|c|c|c|}
\hline \multirow[b]{2}{*}{ Parameters } & & \multirow[b]{2}{*}{$\begin{array}{l}\text { Baseline } \\
(n 1=26, n 2=27)\end{array}$} & \multirow[b]{2}{*}{$\begin{array}{l}\text { 1. Control } \\
\text { (n1=26, n2=27) }\end{array}$} & \multirow[b]{2}{*}{$\begin{array}{l}\text { 2. Control } \\
\text { (n1=26, n2=27) }\end{array}$} & \multicolumn{3}{|c|}{$p$} \\
\hline & & & & & P1 & $\mathbf{P 2}$ & P3 \\
\hline \multirow[t]{2}{*}{ VAS-Rest Mean $\pm S D$} & Group 1 & $29,63 \pm 19,06$ & $14,63 \pm 18,96$ & $8,89 \pm 10,50$ & $0,000 *$ & 0,136 & $0,000 *$ \\
\hline & Group 2 & $31,30 \pm 18,17$ & $13,89 \pm 14,30$ & $14,81 \pm 20,45$ & $0,000 *$ & 1,000 & $0,002 *$ \\
\hline \multirow[t]{2}{*}{ VAS-Activity Mean $\pm S D$} & Group 1 & $67,78 \pm 16,89$ & $37,78 \pm 24,23$ & $32,22 \pm 24,70$ & $0,000 *$ & 0,509 & $0,000 *$ \\
\hline & Group 2 & $68,33 \pm 20,04$ & $36,48 \pm 21,02$ & $39,26 \pm 25,10$ & $0,000 *$ & 1,000 & $0,000 *$ \\
\hline \multirow[t]{2}{*}{ ODI, Mean \pm SD } & Group 1 & $0,47 \pm 0,15$ & $0,31 \pm 0,19$ & $0,31 \pm 0,21$ & $0,001 *$ & 1,000 & $0,002 *$ \\
\hline & Group 2 & $0,46 \pm 0,17$ & $0,39 \pm 0,19$ & $0,35 \pm 0,19$ & 0,365 & 0,675 & $0,010 *$ \\
\hline \multirow[t]{2}{*}{$\mathrm{RDQ}$, Mean $\pm S D$} & Group 1 & $15,00 \pm 4,50$ & $10,70 \pm 5,87$ & $9,15 \pm 7,05$ & $0,002^{*}$ & 0,149 & $0,001 *$ \\
\hline & Group 2 & $14,74 \pm 4,81$ & $11,48 \pm 5,46$ & $10,22 \pm 5,79$ & $0,012^{*}$ & 0,689 & $0,001 *$ \\
\hline
\end{tabular}

n1: Group 1, n2: Group 2, SD: Standard deviation, B: Baseline, C: Control, ODI: Oswestry Disability Index, VAS: Visual Analog Scale RDQ: Roland Morris Disability Questionnaire, * $p<0,05$, P1: B-1.C, P2: 1.C-2.C, P3: B-2.C

When the comparisons between the groups in terms of the changes from the pre-treatment period to the first and the second control visits were made, pain at rest (VASr) $(p=0.204)$ and movement (VASm) $(p=0.311)$, Oswestry Disability Index (ODI) $(p=0.474)$ and the Roland Morris Disability Questionnaire (RDQ) $(p=0.475)$, number of paracetamol tablets used daily $(p=0.092)$, and SF-36 parameters $(p>0.05)$ were not different between both groups.

Then pretreatment, first and second control values were compared. In Group 1, VAS values at rest and during exercise, ODI and RDQ scores were statisti- cally significantly different between pretreatment and first control $(p<0,05)$ (Table 2). In Group 2, all parameters except ODI were statistically significant at 1 st control, and at the same time, this value was also statistically significantly different between the pretreatment, and the second control (Table 2).

In Group 1, there was a difference in the number of daily paracetamol tablets ingested between the first control at the end of treatment and the second control ( $p=0.001)$. In Group 2, there was no difference in the number of paracetamol intake per day $(p=0.121)$. 
Table 3. Comparison of baseline and second control evaluations of the quality of life (short form-36) scores within the groups themselves.

\begin{tabular}{|c|c|c|c|c|c|c|}
\hline \multirow[b]{2}{*}{ Parameters } & \multicolumn{3}{|c|}{ Group $1(n=26)$} & \multicolumn{3}{|c|}{ Group $2(n=27)$} \\
\hline & Baseline & 2. Control & $\mathbf{P}$ & Baseline & 2. Control & $\mathbf{P}$ \\
\hline Physical functioning, Mean \pm SD & $48,47 \pm 18,28$ & $64,11 \pm 25,04$ & $0,004^{*}$ & $49,76 \pm 20,33$ & $62,51 \pm 19,59$ & $0,013 *$ \\
\hline Role Limitations Due To Physical Problems, Mean \pm SD & $12,50 \pm 21,53$ & $46,30 \pm 42,58$ & $0,001 *$ & $18,55 \pm 26,59$ & $50,93 \pm 36,35$ & $0,001 *$ \\
\hline Body pain, Mean $\pm S D$ & $36,25 \pm 16,42$ & $56,85 \pm 23,27$ & $0,002^{*}$ & $39,44 \pm 19,82$ & $60,09 \pm 21,16$ & $0,000^{*}$ \\
\hline Social functioning, Mean $\pm S D$ & $54,55 \pm 19,22$ & $68,50 \pm 20,89$ & $0,009 *$ & $62,90 \pm 15,30$ & $65,73 \pm 19,18$ & 0,468 \\
\hline General mental health, Mean \pm SD & $57,33 \pm 18,68$ & $63,70 \pm 19,91$ & 0,129 & $54,45 \pm 19,40$ & $60,74 \pm 20,73$ & 0,129 \\
\hline Role Limitations Due To Emotional Problems, Mean \pm SD & $38,86 \pm 39,23$ & $55,53 \pm 38,12$ & 0,063 & $33,32 \pm 37,51$ & $45,65 \pm 37,14$ & 0,226 \\
\hline Energy / vitality, Mean $\pm S D$ & $51,17 \pm 20,37$ & $57,78 \pm 21,05$ & 0,123 & $51,29 \pm 22,32$ & $55,56 \pm 24,35$ & 0,770 \\
\hline General health, Mean \pm SD & $48,83 \pm 23,84$ & $50,56 \pm 19,38$ & 0,328 & $45,55 \pm 18,57$ & $48,89 \pm 20,30$ & 0,261 \\
\hline Health status compared with last year, Mean \pm SD & $28,33 \pm 20,48$ & $53,70 \pm 29,17$ & $0,001^{*}$ & $23,45 \pm 19,30$ & $44,44 \pm 32,77$ & $0,005^{*}$ \\
\hline
\end{tabular}

SD: Standard deviation, * $p<0,05$.

When the SF-36 scores were compared, there was a significant difference between the pretreatment and the second control according to the physical function ( $p=0.004, p=0.013)$, physical limitations related to physical problems $(p=0.001, p=0.001)$, body pain $(p=0.002, p=0.000)$, health condition compared to the previous year $(p=0.005, p=0.005)$ in both groups. There was also a significant difference in social functioning scores between the pre-treatment and the second control in Group 1 (Table 3).

\section{DISCUSSION}

In this randomized, double-blind controlled study, traction force applied with $35-50 \%$ of body weight in lumbar disc hernia therapy did not show superiority relative to the traction with $10-20 \%$ of body weight. Improvement in both groups; other than traction, may be associated with other conservative treatments and exercise programs applied.

Studies on management of mechanical back pain with different traction techniques using different weights have shown improvement in clinical parameters of patients ${ }^{13,23-25}$. Tesio et al. ${ }^{23}$ have compared the effects of autotraction and passive traction (35\% of body weight force) on the patients with lumbar disc herniation, although both treatments led to improvement in patients, more pronounced improvement were observed in the autotraction group and autotaxis. They recommended autotraction.
In the study of Guvenol, one group of patients with lumbar disc hernia and waist-leg pain group were subjected to conventional traction for 20 minutes between $30-45 \mathrm{~kg}$ and for the other group, 10 sessions with inversion traction was applied. In addition, all patients were treated with a physical therapy program consisting of using exercise, infarction and corsetry. Their results are similar to our findings, as the two treatment protocols are clinically effective. Unlike the study of Guvenol at al. ${ }^{25}$ improvement in patients studied radiographically with $\mathrm{CT}$ was in favor of conventional traction ${ }^{25}$.

In the meta-analysis in which van der Heijden at al. ${ }^{10}$ used placebo as a control group (low dose traction at about $20 \%$ of body weight), healing was detected in both groups, whereas control group and high dose traction group did not show any improvement ${ }^{16,17,26-}$ ${ }^{28}$. Similar results were obtained in our study.

Leventoglu at al. ${ }^{24}$ have developed a program of medical treatment for the patients with acute lumbar disc herniation in addition to traction with $50 \%$ or $20 \%$ of the patient's body weight, superficial warming, TENS and back exercises. As a result of the study, they found improvement in the functional capacities, and decrease in the disabilty scores of the patients, However TENS was not used in our study, but web obtained comparable clinical and functional improvement. 
In a study where warm package, ultrasound and exercise and in addition to these treatment use of traction therapy with up to $50 \%$ of body weight were compared, there was no significant difference between the treatment groups, although there was a significant improvement within the group in VAS and ODI. In this study by P. Borman et al. ${ }^{29}$ the authors emphasized that regular exercise could improve pain scores and deficits and exercise therapy could be an effective factor contributing to positive outcomes.

In a randomized trial conducted by Thackeray A. et al. two groups of patients with lumbar disc hernias. Group 1 was treated with traction with a load of $40-60 \%$ of body weight, and exercise, and Group 2 with only exercise. In both groups, improvements were observed in VAS and ODI scores but without any intergroup difference ${ }^{30}$. In our study, exercise was added to both groups. Exercise could be the reason why we could not find a difference between groups. In a study by Rattanatharn et al. ${ }^{14}$, similar results were obtained with the same traction loads but not with longer running times of the traction. It is thought that clinical healing may depend on conservative treatment and home programme.

The pain status of patients with low back pain can be determined by VAS scores which directly correlate with a number of parameters in the ODI or RDQ scores as well. ${ }^{20,21,31}$. Decreased pain in both of our study groups can be thought as related to the change in all of these scores. However, the functional assessments we conduct also evaluated daily life activities of the patients. Activities such as sitting, sleeping, weight lifting, bending, traveling are included in daily life activities. Training in preventive measures against low back pain in both groups of patients included arrangements for these activities in daily life. It was thought that there was improvement in functional evaluations in both study groups without any difference between them.

When the effectiveness of the traction was examined, it showed that the definite etiology of waist and leg pain was not clearcut and there were differences between the techniques, and durations of traction and weights used. The number of placebo-controlled studies was also insufficient. Because of these reasons we could not reach a definitive conclusion about the effectiveness of traction ${ }^{10-14}$. Many investigators have indicated the need for randomized controlled trials to determine its effectiveness ${ }^{32-34}$.

Our study had many limitations the traction was applied without localization of hernia, determination of its histopathology. Alterations in discs caused by treatment could not be shown due to the absence of control MRI. The number of patients was not sufficient to arrive at a conclusion. Hot pack, exercise, and medical treatment were applied in addition to traction, but we did not have long term results of the study. It is challenging to interpret the effectiveness of combination treatment of patients with lumbar disc hernia which complicates determination of optimal treatment strategy,18,24. Taking this into consideration, we believe that it may be misleading to link treatment results only to application of traction in our study.

In conclusion, our findings and other studies results suggest that there is a need for more randomized controlled trials about pain reduction in patients with lumbar hernia to show the therapeutic effect of the traction.

\section{REFERENCES}

1. Oğuz H. Tıbbi rehabilitasyon. İstanbul: Nobel Kitapevleri, 200: 1131-71.

2. Murray $\mathrm{CJ}$, Barber RM, et al. Global, regional, and national disability-adjusted life years (DALYs) for 306 diseases and injuries and healthy life expectancy (HALE) for 188 countries, 1990-2013: quantifying the epidemiological transition. Lancet. 2015;386(10009):2145-91. https://doi.org/10.1016/S0140-6736(15)61340-X

3. Alexopoulos EC, Tanagra D, Konstantinou E, Burdorf A. Musculoskeletal disorders in shipyard: prevalence, health care use, and absenteeism. BMC Musculoskelet Disord. 2006;7:88. https://doi.org/10.1186/1471-2474-7-88

4. Kırış T, Turantan i. Lomber disk hastalığı ve cerrahi tedavisi. Fiz Tip ve Reh Derg. 1998: 85-90.

5. Deyo RA, Rainville J, Kent DL. What can the history and physical examination tell us about low back pain? JAMA. 1992;268(6):760-5. https://doi.org/10.1001/jama.1992.03490060092030 
6. Beyazova M, Kutsal Y. G. Fiziksel tıp ve Rehabilitasyon. $3^{\text {th }}$ edition Güneş tıp kitapevi. 2016: 1699.

7. Özcan E. Bel ağrısı. Beyazova M, Gökçe K.Y (Editörler). Fiziksel tıp ve rehabilitasyon. Güneş Kitapevi; 2000:1465-83.

8. Barr KR, Harrast MA. Low back pain. In: Braddom RL (Ed.). $4^{\text {th }}$ ed. Physical medicine and rehabilitation. Philadelphia: Saunders; 2007:883-927.

9. Yıldırım Ç, Bütün $B$, Çubuk $M$, Akyokuş $A$. Akut lomber disk hernilerinde intermitant traksiyon etkinliğinin klinik ve ileri görüntüleme yöntemleri ile değerlendirilmesi. Ege Fiz Tıp ve Reh Derg. 2001;7(1):7-14.

10. Beurskens AJ, de Vet HC, Köke AJ et al. Efficacy of traction for non-specific low back pain: a randomized clinical trial. Lancet. 1995;346(8990):1596-600. https://doi.org/10.1016/S0140-6736(95)91930-9

11. Harte AA, Baxter GD, Gracey JH. The efficacy of traction for back pain a systematic review of randomized controlled trials. Arch Phys Med Rehabil. 2003;84(10):1542-53. https://doi.org/10.1016/S0003-9993(03)00294-6

12. Coxhead CE, Inskip $H$, Meade TW et al. Multicenter trial of physioterapy in the management of sciatic symptoms. Lancet. 1981;1(8229):1065-8. https://doi.org/10.1016/S0140-6736(81)92238-8

13. Pal B, Mangion P, Hossain MA, Diffey BL. Controlled trial of continuous lumbar traction in the tratment of back pain and sciatica. Br J Rheumatol. 1986;25(2):181-3. https://doi.org/10.1093/rheumatology/25.2.181

14. van der Heijden GJ, Beurskens AJ, Koes BW et al. The efficacy of traction for back and neck pain: a systematic, blinded review of randomized clinical trial methods. Phys Ther. 1995;75(2):93-104. https://doi.org/10.1093/ptj/75.2.93

15. Beattie PF, Nelson RM,Michener LA et al. J. Outcomes after a prone lumbar traction protocol for patients with activitylimiting low back pain: a prospective case series study Arch Phys Med Rehabil. 2008;89:269-74. https://doi.org/10.1016/j.apmr.2007.06.778

16. Beurskens AJ, van der Heijden GJ, de Vet HC, et al. The efficacy of traction for lumbar back pain: design of a randomized clinical trial. Manipulative Physiol Ther. 1995;18(3):141-7.

17. Beurskens AJ, de Vet HC, Köke AJ et al. Efficacy of traction for nonspecific low back pain: 12-week and 6-month of a randomized clinical trial. Spine. 1997;22(23):2756-62. https://doi.org/10.1097/00007632-199712010-00011

18. Rattanatharn R, Sanjaroensuttikul N, Anadirekkul P et al. Effectiveness of lumbar traction with routine conservative treatment in acute herniated disc syndrome. J Med Assoc Thai. 2004;87(Suppl 2):272-7.

19. Lee J, Hobden E, Stiell I, Wells G, Clinically important change in the visual scale after adequate pain control Acad Emerg Med. 2003;10:1128-30. https://doi.org/10.1197/S1069-6563(03)00372-5

20. Küçükdeveci $A A$, Tennant $A$, Elhan $A H$, Niyazoglu $H$. Validation of the Turkish version of the Roland-Morris Disability Questionnaire for use in low back pain. Spine. 2001;26(24):273843. https://doi.org/10.1097/00007632-200112150-00024

21. Yakut E, Düger T, Öksüz $C$ et al. Validation of the Turkish version of the Oswestry disability index for patients with low back. Spine. 2004;29(5):581-85. https://doi.org/10.1097/01.BRS.0000113869.13209.03

22. Kesiktas N, Karakas S, Gun K at al. Balneotherapy for chronic low back pain: a randomized, controlled study. Rheumatology International. 2012;32(10):3193-99.

23. Koçyiğit $H$, Aydemir Ö, Fişek $G$ et al. Kısa form-36'nın Türkçe versiyonunun güvenilirliği ve geçerliliği. İlaç ve Tedavi. 1999;12(2):102-6.

24. Tesio L, Merlo A. Autotraction versus passive traction: An open controlled study in lumbar disc herniation. Arch Phys Med Rehabil. 1993;74(8):871-6. https://doi.org/10.1016/0003-9993(93)90015-3

25. Leventoğlu F, Yılmaz H, Uğurlu H. Lomber disk hernili hastaların tedavisinde traksiyonun klinik etkinliği. Ege Fiz Tıp ve Reh Derg. 2004;10(1):23-8.

26. Güvenol K. Lomber disk hernilerinde inversiyon traksiyonuyla konvansiyonel traksiyonun etkinliğinin klinikte bilgisayarlı tomografi ile karşılaştırılması (tez). İzmir: Dokuz Eylül Üniversitesi Tıp Fakültesi; 1995.

27. Matthews LA, Hickling J. Lumbar traction: a doubleblind controlled study for sciatica. Rheumatol Rehabil. 1975;14(4):222-5. https://doi.org/10.1093/rheumatology/14.4.222

28. Krause M, Refshauge KM, Dessen M, Boland R. Lumbar spine traction: evaluation of effects and recommended application for treatment. Man Ther. 2000;5(2):72-81. https://doi.org/10.1054/math.2000.0235

29. Annette A, Harte AA, Baxter GD, Gracey JH. The efficacy of traction for back pain: a systematic review of randomized controlled trials. Arch Phys Med Rehabil. 2003;84(10):154253.

30. Borman P, Keskin D, Bodur H. The efficacy of lumbar traction in the management of patients with low back pain. Rheumatol Int. 2003;23(2):82-6.

31. Thackeray A, Fritz JM, Childs JD, Brennan GP. The effectiveness of mechanical traction among subgroups of patients with low back pain and leg pain: A randomized trial. Journal of Orthopaedics and Sports Physical Therapy. 2016;46(3):14454. https://doi.org/10.2519/jospt.2016.6238

32. Beurskens AJ, de Vet HC, Köke AJ, et al. Measuring the functional status of patients with low back pain assessment of the quality of four disease-spesific questionnaires. Spine. 1995;20(9):1017-28. https://doi.org/10.1097/00007632-199505000-00008

33. Harte AA, Gracey JH, Baxter GD. Current use of lumbar traction in the management of low back pain: results of a survey of physiotherapists in the United Kingdom. Arch Phys Med Rehabil. 2005;86:1164-69. https://doi.org/10.1016/j.apmr.2004.11.040

34. Wegner I, Widyahening IS, van Tulder MW, et al. Traction for low-back pain with or without 489 sciatica. The Cochrane database of systematic reviews. 2013;8.

35. Artus $M$, van der Windt $D$, Jordan KP, Croft PR. The clinical course of low back pain: a meta analysis comparing outcomes in randomised clinical trials and observational studies. BMC Musculoskelet Disord. 2014;15:68. https://doi.org/10.1186/1471-2474-15-68 